\title{
The determinant factors of school organizational change in Madura, East Java, Indonesia
}

\author{
Mochammad Rozikin, Abd. Qadir Muslim, Bayu Indra Pratama \\ Public Administration Department, Faculty of Administration, Universitas Brawijaya, Indonesia
}

\begin{tabular}{l} 
Article Info \\
\hline Article history: \\
Received Feb 12, 2020 \\
Revised Dec 10, 2020 \\
Accepted Jan 23, 2021 \\
\hline
\end{tabular}

\section{Keywords:}

Organizational change Organizational leadership Political pressure

\begin{abstract}
Organizational change is a phenomenon that must be faced and carried out by every individual in the organization to achieve organizational goals. Embodiments of organizational change often occur not because it suits the needs of the organization but because of personal interests and power. This study aimed to determine the main factors that can create change, namely the relationship of leadership and political pressure of school principals that influence organizational change in the Public Secondary School in Madura, East Java, Indonesia. This research used a quantitative approach to survey methods. Based on the achievement of its objectives, this study included causal explanation research, the analysis of this study using Structural Equation Modeling (SEM) and a sample of about 650 people collected from 1000 respondents taken from 130 schools through probability sampling techniques using AMOS software. The results showed that the leadership and political pressure of regional heads were the main factors of organizational change at SMPN (Public Secondary School) in Madura, East Java. Organizational Change depends very much on the role of the political pressure of the regional head through education policy, as well as the role of the principal's leadership in running the wheels of the organization so that the school's goals can be achieved. This study also showed that the principal's leadership as an intermediary variable from political pressure shows no influence because the political pressure of the regional head is directly related to organizational change.
\end{abstract}

This is an open access article under the CC BY-SA license.

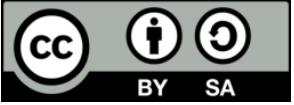

\section{Corresponding Author:}

Mochammad Rozikin

Public Administration Department

Faculty of Administration

Universitas Brawijaya

Jl. MT. Haryono No.163, Kota Malang, Jawa Timur 65145, Indonesia

Email: mochrozikin@ub.ac.id

\section{INTRODUCTION}

Every organization requires an organizational change to maintain its existence during competition and as a tool to achieve organizational goals. Besides, organizational change aims to improve organizational performance so that it becomes better than before. Every change in an organization cannot be separated from innovation, which starts from the process of adopting ideas, techniques/behaviors, so that it can be said that there is a link between organizational change and innovation. The organizational change can be understood as the implementation of innovation towards organization improvement [1]. Organizational change can occur when individual performance in the organization is good. As stated by Lewin [2] and Ford [3], that it requires good performance and effort if you want to achieve good change and increase in the organization. This is evidenced by the results of research Alvesson \& Käreman [4]; Reich, et al. [5]; Grant \& Marshak [6]; and 
Thompson, et al. [7] which states that to make a change requires the performance of each component of the organization, especially the performance of good leaders.

The Ministry of Education and Culture of the Republic of Indonesia continues to improve and strive to make changes to educational institutions. The aim is to advance and improve the quality of Indonesian education to compete in the global sphere. The latest policies in force include: 1) New Student Admission Program in Indonesia (PPDB) by using the zoning mechanism as stipulated in Indonesian Ministry of Education and Culture (Permendikbud) Number 44 of the Year 2019 (Ministerial Regulation) [8]. For 2020, each school must accommodate a minimum of $50 \%$ of new students who live near the school location of the total capacity of new students, $15 \%$ of the affirmation scheme, $5 \%$ of the transfer scheme, and $30 \%$ achievement scheme. This policy aims to equalize the quality of educational organizations. 2) Permendikbud Number 4 of 2018 (Ministerial Regulation) [9] related to the assessment of learning outcomes by the education unit (school), the aim is to provide school freedom in assessing students. 3) Presidential Regulation (Perpres) No. 87 of the year 2017 [10] concerning the strengthening of character education, which is setting related to school authority to determine five or six days to held learning activity with the goal in each day added one hour to strengthen the character of students.

Although the government's efforts are aimed at better change, the main component of a very substantial education has to be solved yet, namely the process and learning outcomes. It is hampering the efforts to changes to produce quality education. The results of research conducted by Muslim [11] found that teaching and learning activities in institutions that were not active, creative, effective, and fun learning cause students to learn in less innovative processes, lack of enthusiasm for learning, and obstructing students' critical thinking skills. According to Muslim [11], the main cause is contextual learning and the imbalance in the application of cognitive, affective, and psychomotor aspects in the learning process.

Evidence of the unsatisfied impact of learning can be seen from the low quality of Indonesian education and cannot compete with ASEAN countries though. For instance, the Mathematics index value in Southeast Asian countries in 2019 obtained an average result of the competence of Indonesian students only reaching level 1 (the most basic). When compared with neighboring countries such as Singapore (level 5), Thailand (level 4), Malaysia (level 3), and Vietnam (level 2). In addition, in the aspect of reading quality and quantity, Indonesia obtained an average value of 396 points, while the value of Malaysia reached 398 points and the average value of Thailand get 441 points [12]. Therefore, it is compulsory for all school members to concurrently solve these problems by maximizing all school components in making organizational changes better, especially in aspects of the learning process. Factors that can create change based on a theoretical study and the results of previous research are politics [13-15] and leadership [3, 16, 17].

Leadership dramatically influences the development of an organization. Reavis [16] confirms the existence of myths that significant changes only occur when it comes to top leadership. That is, it means that there is a relationship between leadership factors and organizational change [3]. However, the principal's leadership today has not played his role as an activator of the entire organization to carry out school plans; consequently, the decisions of the principal and his leadership style are strongly influenced by structural and political interests so that political interests tarnish the task of the school whose purpose is to create a perfect human. The political aspect belongs to the strength of group pressure. According to Suyanto [18], the position of the school headmaster especially often intersects with political aspects. Proximity to the regional mayor or regents becomes a kind of "shortcut" to become a school principal. Those who are excellent at "taking heart" and are in the success-line team-winning of regents or mayors, will comfortably be appointed as school principals even with minimal competence. While professionals who are far from power, do not expect to have a "magic card" to be the principal or headmaster. There are indeed schools' principals who are chosen professionally but minimal in number, and it can even be counted on fingers.

The principal is a political asset for the regional head. The determination of the principal by the regional head is indeed based on the merit system but does not rule out political interests. Not only is to carry out political obligations, but the principal also an instrument to achieve the interests of the regional head. They can be hidden campaigners in the general elections for the second period of regional heads [19]. The principal is also an effective means of control over teacher loyalty in public schools [20]. This role is vital in election campaigns because it can be used to monitor the support of school teachers for incumbent candidates [21]. In addition to leadership, political pressure is correspondingly very momentous in organizational change. The relationship between political pressure and organizational change is studied by the theories of Hoy \& Miskel [14]; Mumby [15]; and Aristotle [22] explaining that politics in organizations is an activity in organizations. There is compromise, consensus, power, and distribution of resources to achieve organizational goals where the organizational changes characterize the activity. Thus, organizational change cannot be carried out without political practice.

However, political practices in schools, especially in Indonesia, influence more towards personal interests not for the progress of the school, for example, ceremonial events are often held in schools to 
conduct imaging and to spend budgets. As a result, the substance of education is untouched and gives birth to human products that are not scientifically and personally qualified. Political practice should be a tool to achieve mutual success, not the success of the interests of a handful of people.

To minimize the political interests, the Ministry of Education and Culture has made many policies or system changes in producing professional school principals. One of them is the establishment of the School Principal Development and Empowerment Institute (LPPKS) as stipulated in the Regulation of the Minister of Education and Culture of the Republic of Indonesia Number 17 the Year 2015 [23] Concerning the Organization and Work Procedures of the Institute for Development and Empowerment of School Principals. LPPKS has the task of carrying out the preparation, development, and empowerment of school principals. With the establishment of this institution, nepotism practices in the appointment of school principals are expected to be avoided. However, the policy of educational autonomy is often a barrier to avoiding practical political practices in schools.

Therefore, this article analyzes the influence of the principal's leadership and the political pressure of the regional head on organizational change at SMPN (Public Secondary School) in Madura, namely analyzing the relationships between variables that influence organizational change using structural equation modeling (SEM). The results of this study are expected to be a recommendation for organizational change in schools. By analyzing the relationship between politics, leadership, and organizational change in state junior high schools in Madura, it can prove the hypothesis of this study that political pressure and leadership influence the realization of organizational change in schools. Also, the results of this study can prove that there are practical political practices in educational institutions, so that they can become the basis for government policymaking, problem-solving, and further development/research.

\section{LITERATURE REVIEW}

Hanson [24] stated that organizational change is the process of implementing innovation on an organization to achieve organizational goals and to adapt to global competition. There are several main things or elements that must be implemented, such as: goals, ideas, people, new methodologies to be used, structures, and interrelated technologies. Daft research results [25] found that organizational change is not separated from the process of adopting ideas, techniques/behaviors within the organization. The purpose of organizational change is to improve and improve organizational performance so that it can develop in the expected direction according to organizational goals. Based on these views, any organizational change cannot be separated from innovation, which starts from the process of adopting ideas, techniques/behaviors, so that it can be said that there is a link between organizational change and innovation. Thus, change can be interpreted as the implementation of innovation towards organizational improvement [26].

Change is a process through specific stages as in the management process, which always starts from planning, implementation, and ends with an evaluation. Robbins [27] found in his analysis that there are three stages in making organizational changes, including unfreezing, namely the condition of an organization that is not performing well and as well as its function, so it needs to be changed. The changing, at this stage is the process of making changes with innovation related to values, attitudes, methods, and others that are considered to be the cause of organizational malfunction, so it needs to be done. The refreezing, a stage of organizational change has occurred and implemented following what expected, so that the changes that occur must be maintained and enhanced. It is different from the opinion of Rogers [28], who proposed five steps of change, namely: knowledge, persuasion, decision, implementation, and confirmation. These steps are classified into a phase, namely the initiation phase which includes information gathering activities, conceptualization, and planning for change and directing the decision to make changes. The second phase, namely implementation, includes the implementation of all the decisions that have been made during the initiation phase.

\section{RESEARCH METHOD}

This research employed a quantitative approach. The design of this study was survey research, which used sample from a population [29]. This research conducted in a wide-ranging population, namely public junior high school in Madura, East Java, Indonesia. This study includes causal explanation research, which is intended to explain the relationship between one and another variable. However, the focus of this research analysis is the path between the independent variables and the dependent variable, so it does not discuss the effect of cause and effect (reciprocity).

This study used a school sample as the unit of analysis, which is determined based on calculations according to Krejcie and Morgan's Table [30]. Individuals who are members of the sample consist of five components, namely: School Principals, School Committee Managers, Teachers, Administrative Personnel, 
and Students, each represented by one person chosen randomly. So, the total number of respondents is 650 from 130 schools. In general, the research sampling technique is called Proportional Random Sampling Area. The reason for using the technique, in line with Kerlinger [29], that it can present the same information from a variety of different respondents employing a census (enumeration and assessment of the whole population) at a much lower cost, much higher efficiency, and sometimes with greater accuracy. The unit analysis of this research is the school that the five components of respondents determined to represent the phenomenon of each school, so the status of the five respondents is the same as the same instrument.

The instrument for collecting data in this study was a questionnaire prepared based on a theoretical grid in the form of a Likert scale. The questionnaire was arranged in the form of five sets each for the Principal, School Committee Managers, Teachers, Administrative Staff, and Students. The questionnaire statement or question applies to all respondents without differentiation, the contents of which refer to the instrument lattice. The questionnaire that was compiled was then performed content validation by requesting consideration from five experts. The foundation of instrument arrangement is shown in Table 1.

Table 1. The foundation of instrument arrangement

\begin{tabular}{|c|c|c|c|}
\hline No & Variable & Sub-variable & Indicator \\
\hline 1 & $\begin{array}{c}\text { Organizational change } \\
{[24,25,27,28,31]}\end{array}$ & $\begin{array}{ll}- & \text { Idea } \\
\text { - } & \text { Structure setting } \\
\text { - } & \text { Behavior } \\
\text { - } & \text { Technology }\end{array}$ & $\begin{array}{l}\text { Vision, mission, innovation, adoption. } \\
\text { Role, function, } \\
\text { Ad hoc institution/committee, facility, procedure. } \\
\text { Attitude, commitment, integrity, moral. } \\
\text { Technology equipment. }\end{array}$ \\
\hline 2 & Politic $[12,14,22,32]$ & 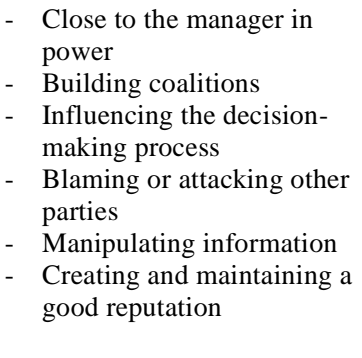 & $\begin{array}{l}\text { Do approach with the ruler, have a good relationship with } \\
\text { the ruler. } \\
\text { Collaborate with internal organizations, build and maintain } \\
\text { communication within the organization. } \\
\text { Conduct influence and approach in the decision-making } \\
\text { process. } \\
\text { Give resistance and blame the opposition. } \\
\text { Providing manipulative information for stability, } \\
\text { Maintaining organizational information against outsiders. } \\
\text { Do a positive image, build and maintain the good name of } \\
\text { the organization. }\end{array}$ \\
\hline 3 & Leadership $[13,27,33]$ & $\begin{array}{ll}\text { - } & \text { Way of work (Procedure) } \\
\text { - } & \text { Organizational functions }\end{array}$ & $\begin{array}{l}\text { Give an example, guide, and liaison member of the } \\
\text { organization, forcing members of the organization. } \\
\text { Make decisions, give certainty to problems. Encourage the } \\
\text { realization of work programs, solve problems. } \\
\text { Give advice }\end{array}$ \\
\hline
\end{tabular}

Following the research objectives, data was collected, tabulated, and analyzed descriptively. Through the application of descriptive analysis, a comprehensive picture of the phenomenon that is the focus of the research is obtained. Besides, the main objective of this study is to determine the relationship both directly and indirectly between exogenous variables and endogenous variables, so that this study uses the Structural Equation Model analysis technique. The analytical method that combines elements of both multiple regression and confirmatory factor analysis, known as the Structural Equation Model [30], is considered appropriate to be used to test the hypothesis model. Data processing with Structural Equation Modeling (SEM) was carried out with the AMOS for the Windows software program.

\section{RESULTS}

Based on previous theory and research, organizational change is influenced directly and indirectly by leadership and political pressure. In this case, the headmaster's leadership becomes an intermediary variable or his indirect relationship with the political pressure of the headmaster with organizational change. Table 2 shows the research results regarding the organizational change determinants collected from various sources. From this conceptual study, the conceptual structural models can be seen in Figure 1. 
Table 2. Determination factors of organizational change

\begin{tabular}{|c|c|c|c|}
\hline No & Previous studies & Variable & Significance \\
\hline 1 & $\begin{array}{l}\text { Hoy \& Miskel [14], Fleenor [34], } \\
\text { Schreuder [35], Trompenaars [36] }\end{array}$ & Politics with organizational change. & $\begin{array}{l}\text { The results of the highest correlation } \\
\text { coefficient conducted by previous } \\
\text { studies [34] amounted to } 0.635=38 \%\end{array}$ \\
\hline 2 & $\begin{array}{l}\text { Reavis [16], Yukl [33], Senge [37], } \\
\text { Segal [38] }\end{array}$ & $\begin{array}{l}\text { Reavis [16], Yukl [33], Senge [37], } \\
\text { Segal [38] }\end{array}$ & $\begin{array}{l}\text { The results of the highest correlation } \\
\text { coefficient conducted by previous } \\
\text { studies [16] amounted to } 0.801=62 \%\end{array}$ \\
\hline 3 & $\begin{array}{l}\text { Hoy \& Miskel [14], Reavis [16], } \\
\text { Fleenor [34], Schreuder [35], } \\
\text { Trompenaars [36] }\end{array}$ & $\begin{array}{l}\text { Politics with the principal's } \\
\text { leadership as an intermediary } \\
\text { variable for organizational change }\end{array}$ & $\begin{array}{l}\text { The results of the highest correlation } \\
\text { coefficient conducted by previous } \\
\text { studies [16] amounted to } 0.612=37.5 \%\end{array}$ \\
\hline
\end{tabular}

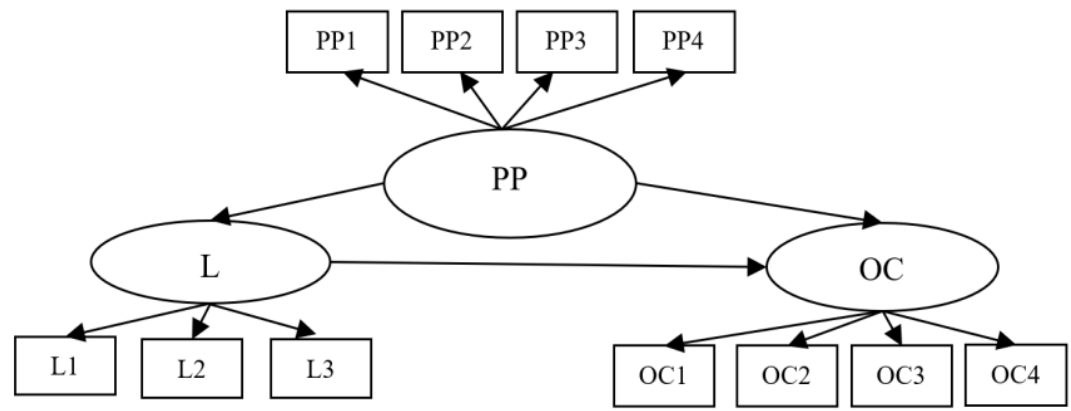

Notes: $\mathrm{OC}=$ Organizational Change, $\mathrm{L}=$ Leadership, $\mathrm{PP}=$ Political Pressure

Figure 1. Structural model

The results of construct analysis using AMOS obtained the relationship of political pressure with organizational change influencing the value of C.R. 4.876 and a $P$ value of $0.00<0.05$. There is a principal's leadership role in creating changes in school organization with a value of 7.568 and a value of $\mathrm{P} 0.00<0.05$. However, there is no relationship between political pressure and principal school leadership as an intermediate variable, with a C.R. 0.89 and P-value 0.12>0.05. Table 3 shows the AMOS output of the construct analysis. Table 4 reveals the results of the model tests on the models offered conceptually.

Table 3. The output of the SEM using AMOS

\begin{tabular}{ccccc}
\hline & Estimate & S.E. & C.R. & P \\
\hline Och $\ll$ Pltc & 0.675 & 0.093 & 4.876 & 0.00 \\
Lead $<$ Pltc & 0.11 & 0.132 & 0.89 & 0.12 \\
Och $<$ Lead & 1.089 & 0.187 & 7.568 & 0.00 \\
\hline
\end{tabular}

Table 4. Model testing results

\begin{tabular}{lccc}
\hline & Testing fit & Model test result & Acceptable match level \\
\hline Absolute fit indices & CMIN & 696.821 & CMIN independence model < CMIN default model < CMIN saturated \\
Incremental fit & NFI & 0.765 & \\
indices & RFI & 0.653 & \\
& IFI & 0.861 & Value range 0-1; approaching 1 the better \\
& TLI & 0.820 & \\
Parsimony fit indices & CFI & 0.531 & \\
& PNFI & 0.603 & Value range 0-1 \\
& PCFI & 0.495 & Value range 0-1 \\
\hline
\end{tabular}

The test results of the model offered by the previous research are fit and acceptable, although the CMIN value is quite significant, the value is smaller than the default CMIN value of the model. In the incremental fit indices, NFI obtained a value of 0.765 , which means quite high and accepted, RFI obtained a value of 0.653 , indicating that this model is fit, IFI obtained a result of 0.861 , which means fit, TLI obtained a result of 0.820 , which means this model is accepted, and the last is CFI value of 0.531 means that it is quite acceptable even though the CFI results are lower than others. Whereas in the parsimony fit indices, for PNFI values obtained 0.603 results and PCFI values obtained 0.495 , both indicators are of sufficient value and this model is accepted because the values are at vulnerable $0-1$. 


\section{DISCUSSION}

Organizational change will be achieved and occurred with the influence of political pressure and leadership of the school principal as shown in Figure 2. In this case, political pressure and leadership of the school principal are factors that directly influence organizational change.

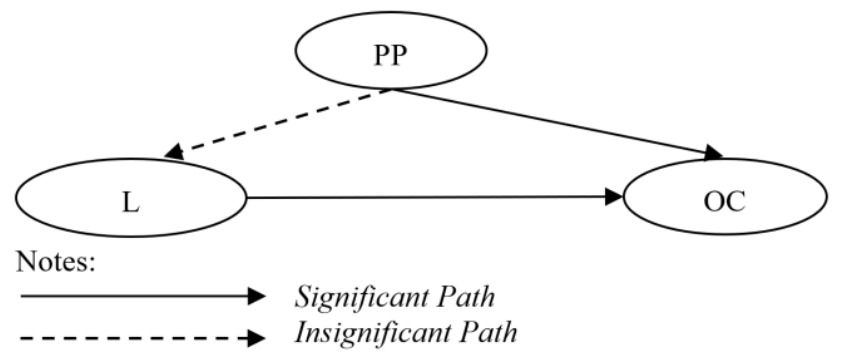

Figure 2. The result of the research

This reinforces the results of previous research and theories, including Mumby [15]; Pieterse [39]; Balogun and Hope-Hailey [40]. This explains that strategies and behaviors to influence organizational personnel in preparing or making organizational changes are political practices carried out by the authorities or stakeholders so that the objectives organization can be achieved. Aristotle [22]; Thompson [41]; and Burke [42] assert that organization or society cannot be separated from politics, because humans as members of organizations are basically "political animals", that is, only within an organization that politicians have members the organization can live a good life. From this perspective, politics means an ethical activity related to the effort to create a "developed organization". That effort is called the process of organizational change for the better. Based on the theory and previous research above, it can be emphasized that political pressure or practice within organizations is a significant factor in organizational change at public secondary school in Madura, East Java, Indonesia.

Hoy and Miskel [14] as well as Mumby [15] explained that strategies, behaviors, work programs to influence individual organizations in preparing or realizing organizational change are political practices carried out by the authorities or stakeholders so that organizational goals can be achieved. Heywood [13] also corroborated the results of this study that politics in organizations is an activity in organizations in which there is a compromise, consensus, power, and distribution of resources to achieve organizational goals, the activity is characterized by organizational change. Based on this, it is clear that organizational change cannot be carried out without political practice.

Besides being directly influenced by political pressure, organizational change is also directly influenced by the leadership of the school principal. These results in line with Burnes and By [43]. They argued that to make organizational change through the leadership process intervention in the organization so that changes occur. In other words, organizational change in schools occurs because of the principal's leadership. In this study, the principal's leadership has a significant direct effect on organizational change. The results of this study support the opinion of Herold, et al. [44] that the leader becomes an agent of change and significant change only occurs when there is a role of a leader. Leadership as a major factor in making changes in the organization is also strengthened by the results of previous studies including Pieterse [39]; Balogun \& Hope-Hailey [40]; Charissa, et al. [45]; White and Cicmil [46], which concluded that there are four principles in the success of organizational change, namely: culture of success, capacity building, systems thinking, and leadership for success. Of the four pillars, there is leadership for success factors, which means that successful and effective leadership together will create better organizational change.

The role of the principal's leadership can be optimal if all components in the school support the overall style and behavior of the principal in leading. Research conducted by Reich, et al. [5]; Grant \& Marshak [6]; Pieterse, et al. [39]; Doyle [47]; Burnes [48] that individual behavior, in this case, the principal cannot be separated from the influence of internal and external factors of the organization, namely personal needs, work environment, group pressure, and task demands. The leader's reaction to the four forces determines how well the organization works. Understanding how these four forces affect individuals allows leaders to behave in a better overall manner with others. Based on some of the opinions and research put forward above, the author can conclude that in order to make organizational changes to a useful and effective public secondary school in Madura, East Java, Indonesia the main factor is the direct role of the principal's leadership to make it happen. 
Also, the success of organizational change requires a change agent, a person who carries out a process of influencing all personnel of the organization to receive the program, creativity and innovation based on the goals planned by the reformer. Thus, the main task of the reform agent is to generate ideas, creativity, and innovation in the form of work programs from reformers to individual organizations. The leader of an educational institution is an agent of change who is obliged to make changes to his organization. The main function of change agents according to Rogers [28] is to make members of the organization aware of the need for a change in attitude or commitment to accept the change process, by compiling information to be conveyed, identifying individual organizational problems, conveying the purpose of the change to all personnel, stabilizing the adoption of the change process, fortifying from disruption the process of change implemented, and maintain harmonious relationships with all stakeholders.

Therefore, in implementing organizational change in educational institutions, leaders must function as agents of innovation and reform. All ideas of change that become school programs or in the form of government policies must be poured and concreted into work programs, teaching and learning in schools. The change process can be realized successfully if the school principal carries and leads the school following the jointly determined change work plan. Based on this reason, schools' principals must understand organizational change comprehensively (strategies and constraints) before carrying out the process of organizational change [26].

The principal as an agent of reform is also required to have insight into management and systems in managing and creating change in schools, namely an understanding of changes that are innovative, dynamic and integrative [49]. This understanding is not limited to changes in teacher personnel, education staff or curriculum structure, teaching-learning processes or school administration partially but all aspects of the school are seen as an inseparable part of the change process. For example, the headmaster is supported by all sections in the school collaboratively so that all personnel can also serve as agents of change [27].

Luthans [31]; and Kärreman \& Alvesson [50] reflect the results of research that have implications for organizational change, namely: 1) Change agents must focus on systematic changes in work settings as a starting point for change and changes in individual behavior as key mediators associated with changes in organizational results. 2) Technological interventions indicate that negative behavior changes. In some cases, an organization can wait for changes in negative behavior until all individuals can overcome learning barriers or have successfully adapted to the changes that have been made. 3) Well-developed theories must provide a better basis for choosing interventions rather than merely changing the style, values and personal choices of the parties concerned.

The proposition of the results of this study is the realization of organizational change resulting from the relationship of political variables, leadership, and organizational change marked by ideas in the process such as vision-mission which is suitable for the needs of the times and members of the organization. There are creativity and innovation in each program and have an effective strategy and adoption at every step. Furthermore, the success of organizational change can also be seen from the set structure to facilitate the implementation of change. For instance, a new department was formed to oversee changes, the existence of procedures, providing facilities for the creation of organizational change, and the role and function of each member in making changes. The change process can be successful if it is followed by a change in the behavior of all members of the organization which is marked by the attitude of accepting change, commitment to making changes, and having the moral integrity of each individual so that organizational change can be realized. The other forms of successful organizational change are the availability of tools, technology mastery, and the mastery of the knowledge of each organization, as support to adapt to the times.

\section{CONCLUSION}

Organizational change in public junior high school in Madura, East Java is directly affected by the political pressure of the regional head and school principal's leadership. However, this change was not affected indirectly by political pressure through the leadership of the school principal. The change in school organization depends on the education policy directly by the regional head in leading his community. The results of this study can be used as a foundation for academics and school organizations, so that organizational change can be achieved properly and effectively.

\section{REFERENCES}

[1] Hussey, D.E., How to Manage Organizational Change. London: Kogan Page limited, 2000.

[2] Lewin, K., "Group Decision and Social Change," in Newcomb, T. M., and Hartley, E. L., Eds. Readings in Social Psychology. New York: Henry Holt, 1947, pp. 330-344. 
[3] Ford, M.W., "Supply Chain Quality Management and Environmental Uncertainty: A Contingency Perspective," Quality Management Journal, Vol. 22, No. 4, pp. 54-65, 2015.

[4] Alvesson, M. and D Ka"rreman, "Decolonizing Discourse: Critical reflections on organizational discourse analysis," Human Relations Journal, Vol. 64, No. 9, pp. 1121-1146, 2011.

[5] Reich, B. H., et al., "Developing Better Theory About Project Organizations," International Journal of Project Management, Vol, 31, No. 7, pp. 938-942, 2013.

[6] Grant, D. and Marshak, R.J., "Toward a Discourse-Centred Understanding of Organizational Change," The Journal of Applied Behavioural Science, Vol. 47, No. 2, pp. 204-35, 2011.

[7] Arthur A. Thompson, A.J. Strickland, and Gamble, J., Crafting and Executing Strategy, 18th Ed. McGraw Hill, 2012.

[8] Minister of Education and Culture Regulation concerning No 44/2019 about Student Admission.

[9] Minister of Education and Culture Regulation concerning No 4/2018 about Study Assignment.

[10] President Regulation 87/2017 about concerning Character Building.

[11] Muslim, Abd. Qadir, "The Declining Quality of Learning in the Implementation of Learning Education Administration Education Study Program Faculty of Administrative Sciences," Universitas Brawijaya, Report on the Actualization of CPNS Kemendikbud 2020 Basic Training. BBPK Makassar, 2020.

[12] Minister of Education and Culture, Asean Education Quality. Jakarta: Website Kemendikbud, 2019.

[13] Heywood, A., Politik. Pustaka Pelajar: Yogyakarta, 2014.

[14] Hoy, W.K. and Miskel, C.G., Educational Administration: Theory, Research, and Practice. McGraw-Hill: Singapore, 2008.

[15] Mumby, D.K., "Power and politics", in Jablin, F.M. and Putnam, L.L., Eds. The New Handbook of Organizational Communication. Sage Publications, London, 2017.

[16] Reavis, R. D., Graziano, P. A., Keane, S. P., and Calkins, S. D., "The Role of Emotion Regulation in Children's Early Academic Success," Journal of School Psychology, vol. 45, no. 1, pp. 3-19, 2010.

[17] Kelner, S., "Human Motivation and Organization Mobilition," Center for Quality of Management Journal, Summer, vol. 9, no 1, pp. 25-43, 2008.

[18] Suyanto., Reflections and Educational Reform in Indonesia Entering the Industrial Age 4.0. Yogyakarta: Adicita, 2017.

[19] Lazar, S., "Personalist Politics, Clientelism and Citizenship: Local Elections in El Alto Bolivia," Bulletin of Latin American Research, vol. 23, no. 2, pp. 228-243, 2004.

[20] Persson, A., Andersson, G., and Nilsson L., "Successful Swedish Headmasters in Tension Fields and Alliances," International Journal of Leadership in Education, vol. 8, no. 1, pp. 53-72, 2006.

[21] Pierskalla, J. H. and Sacks, A., "Personnel Politics: Elections, Clientelistic Competition and Teacher Hiring in Indonesia," British Journal of Political Science, vol. 3, no. 2, pp. 1-23, 2018.

[22] Aristotle, Politic. New York: Oxford University Press, 1995.

[23] Minister of Education and Culture Regulation No 17/2015 concerning Organization Dan The Work Procedure of the Principal's Development and Empowerment Institute.

[24] Hanson E.M., Educational Administration and Organizational Behavior. Boston: Allyn and Bacon, 1996.

[25] Daft, R. L., New Era of Management. Thomson/South-Western, 2008.

[26] Setyadin, B., "Relationship of Organizational Learning, School Organizational Culture, Leadership to Motivation and Organizational Change," Disertation, Universitas Negeri Malang, 2010.

[27] Robbins, SP. and Judge, Organization Behaviour. Salemba Empat, Jakarta, 2011.

[28] Rogers, M.E., Diffusion of Innovation, 5th Ed. New York: Free Press, 2003.

[29] Kerlinger, F.N., Foundation of Behavioral Research, 2nd ed. New York: Holt Rinehart \& Winston. Inc, 1973.

[30] Hair, et al., Multivariate Data Analysis, 7th Ed. Pearson Prentice Hall, 2010.

[31] Luthans, F., Organization Behaviour. Yogyakarta: ANDI, 2016.

[32] Albrecht, K., Organization Development. Bandung: Angkasa, 2010.

[33] Yukl, G., Leadership in Organization, 5th ed. Jakarta; PT Indeks, 2010.

[34] Fleenor, J.W., Leadership Effectiveness and Organizational Culture: An Exploratory. Toronto, Canada, 2012.

[35] Schreuder, J., "Implication of Culturally Based Assumptions of Leadership for the Process of Educational Transformation," Educational Management \& Administration, vol. 62, no. 2, pp. 37-61, 2017.

[36] Trompenaars, F. and Charles H.T, Riding the Waves of Culture (5th Eds). London: Nicholas Brealy Publishing, 2010.

[37] Senge, P.M., The Fifth Discipline: The Art and Practice of The Learning Organization (4th Edition). London: Century, 2011.

[38] Segal, M., Points of Influence: A guide to Using Personality Theory at a Work (3rd Edition). San Fransisco: JosseyBass, 2015.

[39] J. H. Pieterse, M.C.J. Caniëls, and T. Homan, "Professional Discourses and Resistance to Change," Journal of Organizational Change Management, vol. 25, no. 6, pp. 798-818, 2012.

[40] Balogun, J. and Hope-Hailey, V., Exploring Strategic Change. London: Prentice Hall, 2004.

[41] Thompson, J. D., Organizations in Action. New York: McGraw-Hill, 1967.

[42] Burke, W. W, Organization Change: Theory and practice. Thousand Oaks, CA: Sage, 2011.

[43] Burnes, B., By, R.T., "Leadership and Change: The Case for Greater Ethical Clarity," J Bus Ethics, vol. 108, pp. 239-252, 2012, doi: https://doi.org/10.1007/s10551-011-1088-2. 
[44] Herold, D., Fedor, D., Caldwell, S., and Liu Y., "The effects Of Transformational and Change Leadership on Employees' Commitment to Change: A Multiple Study," Journal of Applied Psychology, vol. 92, no. 2, pp. 346-357, 2008.

[45] Freese, C., Schalk, R., and Croon, M., "The impact of organizational changes on psychological contracts: A longitudinal study," Personnel Review, Vol. 40, No. 4, pp. 404-422, 2011, doi: 10.1108/00483481111133318.

[46] White, G. and Cicmil, S., "Knowledge Acquisition Through Process Mapping: Factors Affecting the Performance of the Work-Based Activity," International Journal of Productivity and Performance Management, vol. 65, no. 3, pp. 302-323, 2016.

[47] Doyle, M., "From Change Novice to Change Expert: Issues of Learning, Development and Support," Personnel Review, vol. 31, no. 4, pp. 465-481, 2002.

[48] Burnes, B., Managing Change: A Strategic Approach to Organizational Dynamics. Harlow: Prentice Hall, 2004.

[49] B. M. Kathleen, The Vendor's Role: Assisting Customers with Change Management. Proquest, 2011.

[50] D. Ka"rreman and M. Alvesson, "Resistance to Change: Counter-Resistance, Consent and Compliance in a Consultancy Firm,” Human Relations, Vol. 62, No. 8, pp. 1115-1144, 2009. 